\title{
Primer synovialis chondromatosis a bokaízületben
}

\author{
DR. KOÓS ZOLTÁN
}

\section{ÖSSZEFOGLALÁS}

A synovialis chondromatosis egy ritka benignus tumorszerű elváltozás, amely általában csak egy ízületet érint. Leggyakrabb előfordulási helye a térdízület, majd ezt követi a csípő-, a váll- és könyökízület. Bokaízületben ritkán fordul elő, magyarországi közlés ebben a lokalizációban eddig nem történt. A szerző saját esetét ismerteti, a synovialis chondromatosis irodalmának áttekintése mellett, külön felhívva a figyelmet a diagnosztikus nehézségekre.

\section{Kulcsszavak: $\quad$ Boka; Chondromatosis; Synovialis chondromatosis;}

Z. Koós: Primary synovial chondromatosis in the ankle joint

Synovial chondromatosis is a rare, benign, tumor-like condition that usually involves only one joint. Most frequent localization is the knee joint followed by the hip, the shoulder and the elbow. It is quite rare in the ankle joint. In this joint no case has been published in Hungary so far to our knowledge. The author presents his own case with a review of the literature, paying special attention to the diagnostic difficulties.

Key words: $\quad$ Ankle joint - Surgery; Chondromatosis, synovial - Surgery; Synovial membrane - Surgery; 


\section{BEVEZETÉS}

A primer synovialis chondromatosis egy ritka benignus tumorszerű elváltozás. Ismert a synovialis chondrometaplasia, valamint Reichel-Jones-Henderson szindróma elnevezése is. Gyakorisága pontosan nem ismert. Általában 30-50 éves kor között jelentkezik. Férfiakban kétszer gyakoribb, mint nőkben (26).

$\mathrm{Az}$ abnormális synovium intima rétegének porc metaplasiája következményeként a synovium több helyen szigetszerűen porcot termel, az így keletkezett chondromák a synoviumról leszakadhatnak és szabadtestként viselkedhetnek. A szabadtestek nőhetnek, calcificalódhatnak, ossificalódhatnak. Az ossificalódott megjelenés esetén használható a synovialis osteochondromatosis elnevezés. A betegség nem terjed a test egyéb részeire, viszont lokálisan ízületi destrukciót okozhat és arthrosishoz vezethet.

Három stádiumát különböztetjük meg. Korai szakasz alatt az aktív synovialis szakaszt értjük szabadtestek nélkül. $\mathrm{Az}$ átmeneti szakaszban még mindig aktív a synovialis betegség, viszont a synoviumon kialakult osteochondralis csomók mellett levált szabadtestek is találhatók az ízületben. A késői szakaszra jellemző a szabadtestek jelenléte aktív synovialis betegség nélkül (16).

A betegség általában egy ízületet érint, de ismertek több ízületet érintő közlemények is (21). Leggyakrabb előfordulási helye a térd, az esetek 60-70\%-ában, utána következik a csípő-, a váll-, és könyökízület $(6,19)$. Bokaízületben ritkán fordul elő (12). Irodalmi ritkaságként leírták már többek közt rágóizületben, intervertebralis ízületben, a második metatarso-phalangealis ízületben és a hüvelykujj interphalangealis ízületében is $(1,3$, 11, 18). Ízületi lokalizáció mellett publikálták ínhüvelyből, illetve bursából kiinduló előfordulását is $(13,14)$. Magyarországi közlés bokaízületi primer synovialis chondromatosisról eddig nem történt.

\section{ESETISMERTETÉS}

Egy 45 éves férfi jelentkezett a szakrendelésünkön, akinek elmondása szerint 6 évvel korábban kezdődött a jobb külboka mentén jelentkező fájdalma és fokozatosan növekvő duzzanata, amelyet nem tudott akkori friss sérüléshez kötni. Jó általános állapotú, normál testalkatú, az átlagnál jelentősen magasabb termetú, értelmiségi foglalkozású, korábban rendszeresen sportoló férfiról van szó, akinek belszervi betegsége nem ismert, appendectomián kívül más mútéte nem volt és gyógyszereket rendszeresen nem szedett.

Anamnéziséből a jobb bokaduzzanat ki-

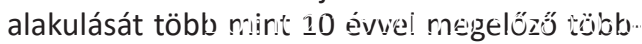
szörös jobb bokatáji indirekt inverziós mechanizmusú és egyszeri direkt lágyrész trauma emelhető ki. A beteget más intézetben rendszeresen követték. Több alkalommal történtek különböző képalkotó vizsgálatok, amelyek leletei nem voltak koherensek a diagnózist illetően. Talán ez is hátráltatta a helyes diagnózis felállítását, illetve a kezelés elkezdését. Több korábbi röntgenlelet szerint észlelték a kóros folyamatot, azonban myositis ossificansnak, amiloidosisnak vagy meszesedett bursitisnek írták le azt. Ultrahang vizsgálat a fibula korábbi avulsiós törése utáni állapotnak írta le. Izotópos vizsgálat és $C T$ is irritatív csont folyamatot véleményezett, amely után endokrinologiai kivizsgálás történt, negatív eredménnyel. Ezt követően, mikor már három éve fennálltak a panaszai, akkor TeleCobalt besugárzást kapott, amely után 6 hónapig a bokatáji duzzanat növekedése megállt, azonban utána újra tovább növekedett. Két alkalommal is készült mágneses rezonancia (MR) vizsgálat, utoljára egy évvel a szerző által történt első észlelése előtt (1. ábra). Mindkét MR lelet egyértelmúen synovialis osteochondromatosist véleményezett. Biopsia is történt, amely osteochondroma részletet írt le, azonban mütétre mégsem került a beteg 6 éven keresztül.

Intézetünkben történt első észlelésekor, a külboka duzzanata férfi ököl nagyságú volt, a sarkat varusba tolta és a felső ugróízületben enyhe equinus tartás alakult ki (2. ábra). A subtalaris ízületben mozgás nem volt kivihető. A beteg komoly cipőviselési problémákkal küszködött és enyhe sántítással járt. Ekkorra már arthrosisos jelek is láthatók voltak a röntgenfelvételeken az elülső és hátulsó impingement radiológiai jelei mellett (3. ábra). Feltárása során a conglomeratummá összeállt chondromák eltávolítása és részleges synovectomia történt (4. ábra). Szövettani vizsgálat igazolta a synovialis chondromatosist. 
A bokát neutrális helyzetbe tudtuk hozni, viszont a mozgástartomány a mútőasztalon érdemben nem javult. Rendszeres, intenzív gyógytorna eredményeként, 12 héttel a mútét után sántítás nélkül, segédeszköz nélkül járt.
Boka- és subtalaris ízületi mozgásai is javultak, bokakörzést is képes volt kivitelezni. A mindennapi életben fájdalma nincs, de megterhelésre mérsékelt bokatáji duzzanat jelentkezik, amely pihentetésre szűnik.
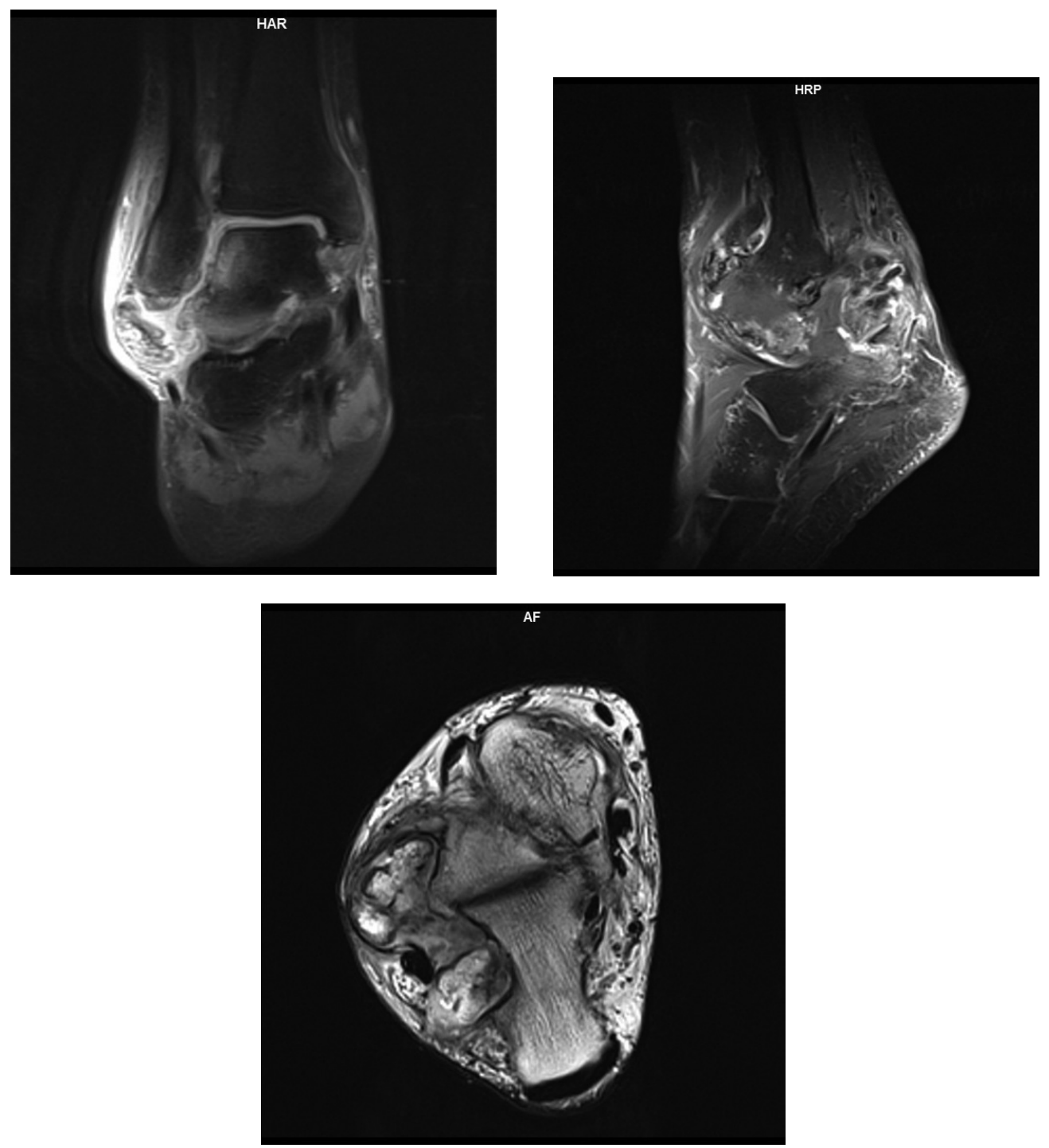

1. ábra A jobb bokáról készült MR felvételeken egyértelmüen látszanak a chondromák
(a) frontális
(b) sagittalis
(c) axialis 

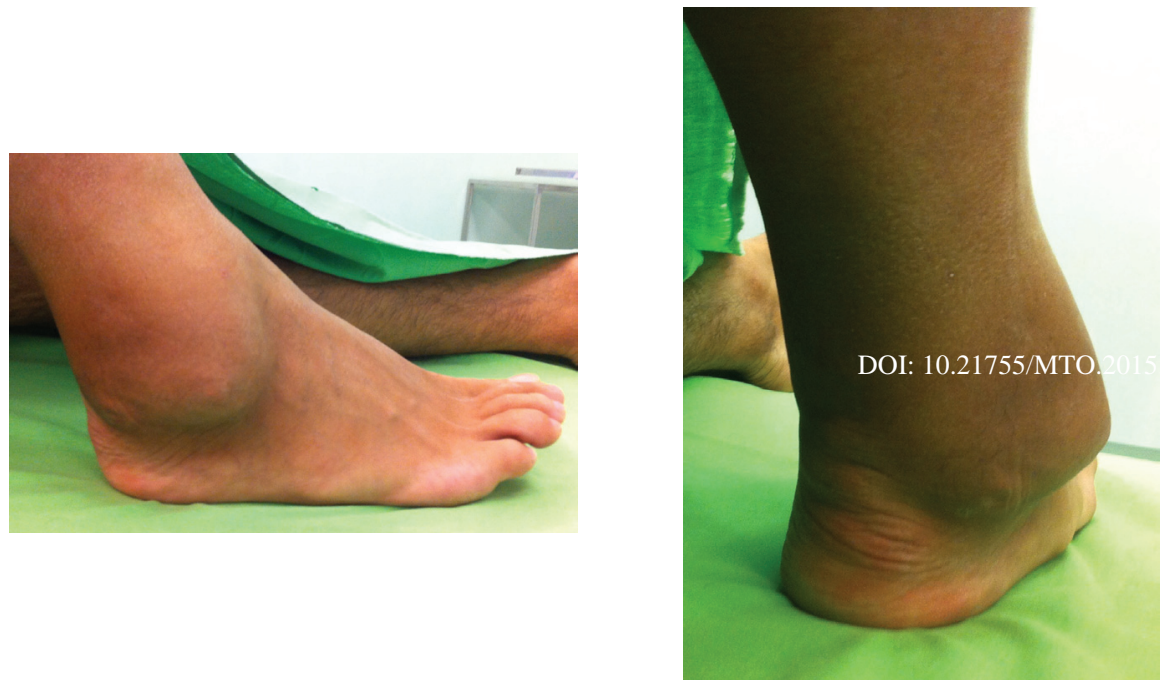

2. ábra A jobb külboka mentén férfiököl nagyságú duzzanat volt észlelhető
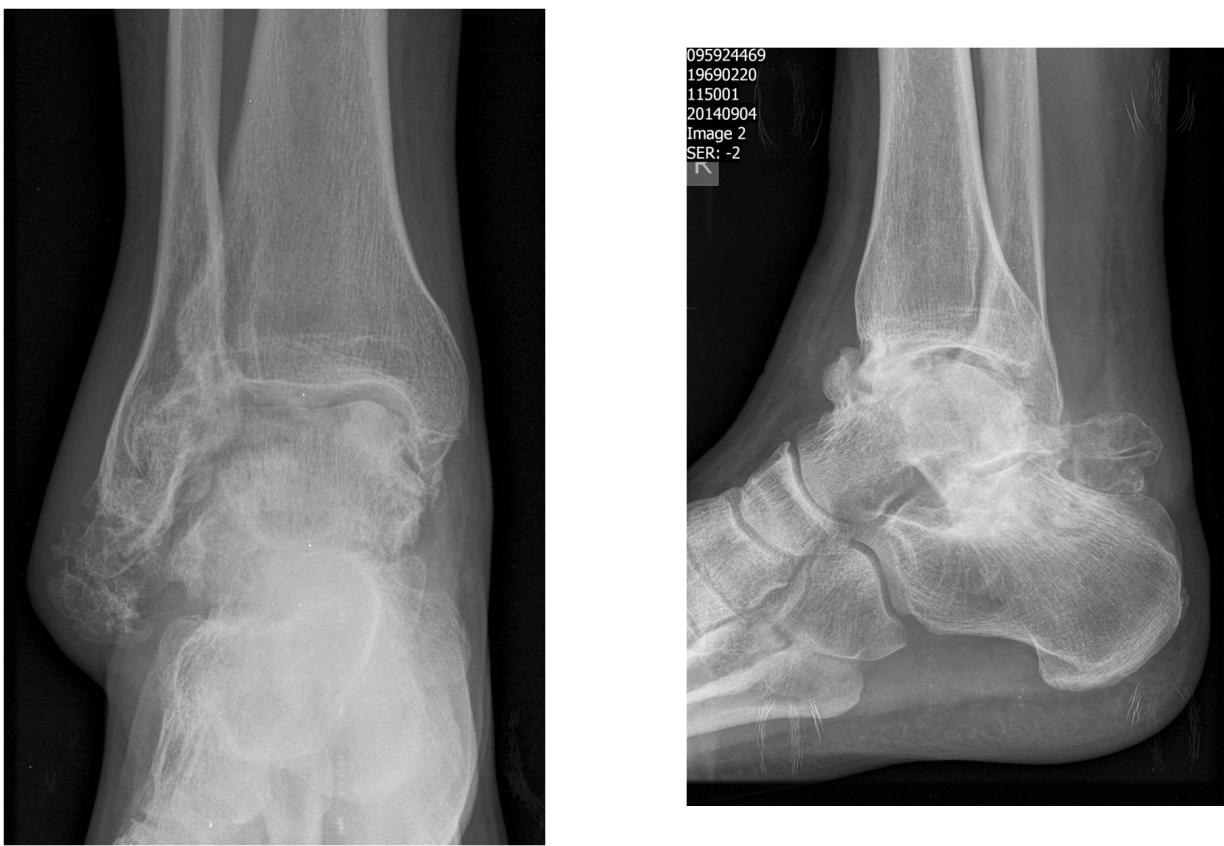

3. ábra Antero-posterior (a) és oldal irányból (b) készült nativ röntgenfelvételeken elülső és hátulsó impingement és arthrosis jelei látszanak 

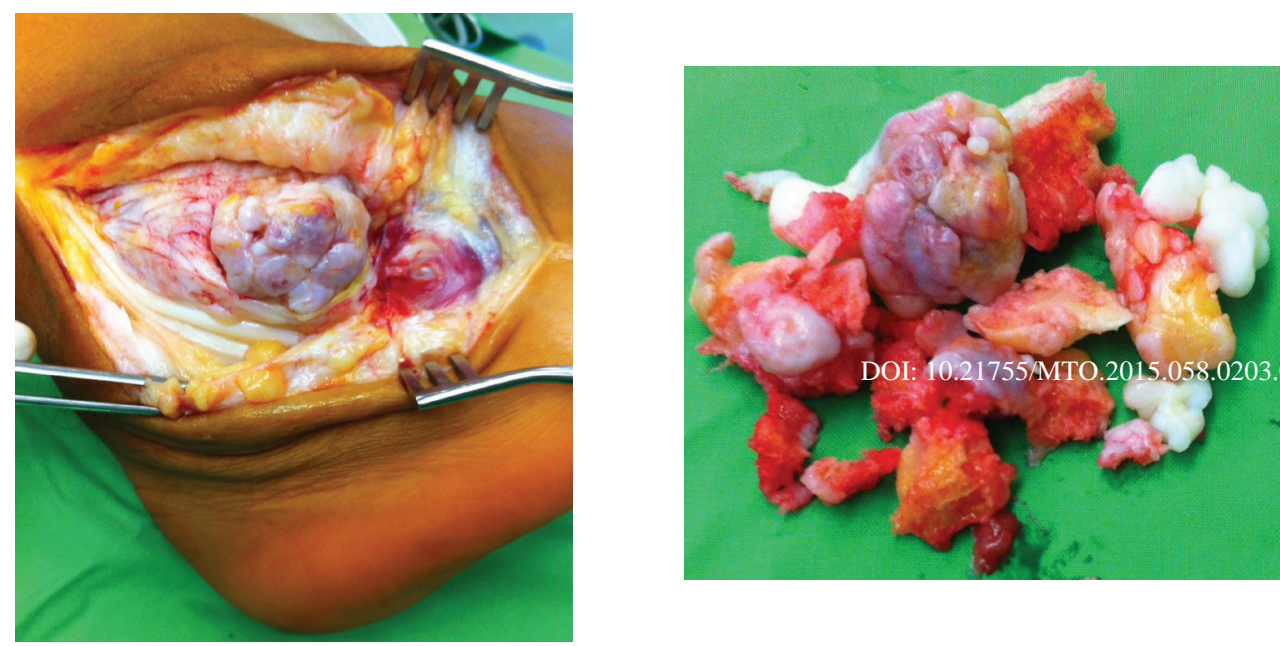

4. ábra A mütéti feltárás során észlelt, conglomeratummá összeállt chondromák in situ (a), majd eltávolítva (b)

\section{MEGBESZÉLÉS}

\section{Diagnosztika}

A primer synovialis chondromatosist diagnosztizálni a betegség korai szakaszában nem egyszerü. Primer formájának etiológiája nem ismert pontosan, de sok eset hátterében a távolabbi múltban történt traumát lehet felfedezni, ami után beindul a synovium kóros viselkedése. Bemutatott esetünkben is említésre került több évvel korábban elszenvedett többszörös trauma. A synovialis chondromatosis szekunder formája sokkal gyakoribb, ilyenkor meglévő primer arthrosis, rheumatoid arthritis, osteochondritis dissecans, osteonecrosis, TBC, vagy neuropathiás eredetű arthrosis talaján alakul ki. A szekunder formát azonban jelen írás keretében nem tárgyaljuk. Primer betegség esetén a szabadtestek és a synovium szövettani mintáiból magas bone morphogenetic protein 2 (BMP-2) és BMP-4 mutatható ki, amelyek facilitálják a porc és csont metaplasia létrejöttét (20).

A primer forma általában 30-50 év között jelentkezik, de fiatalabb életkorban, sőt gyermekkorban is előfordulhat (13). A fizikális vizsgálat során a korai szakaszban synovitis vagy arthritis tünetei észlelhetők, ilyenkor nincsenek jellegzetes tünetei. Az átmeneti és a késői szakaszban mozgásterjedelem csökkenés, esetleg crepitatio vagy fizikálisan tapintható szabadtestek, elakadásos tünetek, illetve arthrosis tünetei lehetnek jellemzőek. Eleinte szivacsos tapintatú a duzzanat, későbbi stádiumban kemény, akár csontos tapintatú. A korai szakaszban igen nehéz diagnosztizálni. Ilyenkor a közelmúltban ismert trauma nélkül kialakult fájdalom, diszkomfort lehet az egyedüli, amelyhez normál laborok társulnak (We, CRP, fehérvérsejtszám, Borrelia titer, Rheuma Faktor). Másodlagos chondromatosisnál ezek a laborértékek magasabbak lehetnek. Az ízület pungálása során nyert synovialis folyadék sem mutat eltérést bakeriológia, sejtszám, kristály vizsgálat és Gram festést illetően sem. A punctatum chondrocalcin meghatározása kórjelző lehet, de jelenleg ez a módszer túl drága a rutinszerű alkalmazás bevezetéséhez (10).

A röntgenfelvétel a korai szakaszban negatív, később a calcificálódott chondromák látszanak a felvételen. Összességében 5-30\%-ban negatív a lelet. Ahogy bemutatott esetünk is bizonyítja, a radiológus számára osteographiás felvételek alapján komoly differenciáldiagnosztikai problémát jelent a chondromatosis.

MR vizsgálattal viszont jól látszanak a synovialis chondromák, akkor is, ha a röntgen negatív. T2 súlyozott felvételeken magas szignál intenzitású laesiók ábrázolódnak. Gadolinium kontraszt anyag alkalmazásával pedig, a nagyobb szenzitivitás miatt 
egyértelmúbb az MR kép (15).

Biopsiával bizonyítható a végső diagnózis. Hematoxylin-eozin festéssel a vastag, villózus synovialis membrán sziget-szerű chondrocyta csoportosulásokkal látható. Diszkrét alacsony sejtszámú hyalin porc lebenyek figyelhetők meg egy vastag rostos réteggel körülvéve. A chondrocyta csoportokat osteoclast szerü óriássejtek és denz, eosinophil cytoplazmájú chondroblastok szegélyezhetik. Késői stádiumban a chondrocyta csoportok valódi ossificatiója mehet végbe vascularis invázió és enchondralis csontképződés által (26).

\section{Kezelés}

A konzervatív kezeléstől primer synovialis chondromatosis esetén nem várható, hogy a folyamatot visszafordítsa. Besugárzás hatásáról született ugyan közlemény, ami egy esetben recidíva esetén megállította a recidíva progresszióját (4).

A chondromák nyílt vagy artroszkópos eltávolítása és részleges synovectomia a választandó mútéti megoldás. Elméletileg a részleges synovectomia után magasabb recidíva aránnyal kellene számolni, azonban figyelembe véve azt, hogy totál synovectomia után nagyobb az ízületi merevség kialakulásának az esélye, mégis a részleges synovectomia az ajánlott módszer (5).

A recidíva arány az irodalmi adatok alapján változó, de viszonylag alacsony (1-20\%). Ennek ellenére az esetek 25\%ában az adott ízületben később további mútétre van szükség, az arthrosis progressziójának függvényében $(2,25)$. Térd esetén alacsonyabb, boka és láb esetén magasabb a kiújulás rizikója (12). Artroszkópos technika alkalmazása után rendszerint magasabb recidíva arányról számolnak be a közlemények, azonban a bokán végrehajtott sikeres recidíva nélküli artroszkópos mútétről is ismerünk adatokat $(8,22)$. A bemutatott esetnél a késői stádium, valamint az ízület elülső és hátulsó érintettsége miatt a conglomeratummá összeállt osteochondromatosist artroszkóposan nem lehetett volna maradéktalanul eltávolítani, emiatt döntöttünk a feltárásból végzett mútét mellett.

Malignizálódás meglehetősen ritka, de ismertek az irodaiomban dokumentált esetek $(9,17,23,24)$. Bár egyes vélemények szerint a chondrosarcomává alakulás annyira ritka, hogy az észlelt esetek többségében egyszerüen az elsődleges diagnózis volt téves, egy 1998-ban történt vizsgálat szerint a malignizálódásra való hajlam 5\% volt (7). Emiatt, illetve az okozott arthrosis progressziója miatt primer synovialis chondromatosis eseteiben rendszeres kontrollvizsgálatok szükségesek.

\section{Konklúzió}

Monoarticularis synovitis okozta panaszok esetén, amelyek nem tűnnek traumás eredetűnek, 30-50 éves életkorú betegnél, negatív labor vizsgálatok és negatív röntgen mellett gondoljunk a synovialis chondromatosis lehetőségére! A képalkotó vizsgálatok közül a szerző a bemutatott eset és az irodalom alapján $M R$ vizsgálat elvégzését ajánlja synovialis chondromatosis gyanúja esetén. A diagnózis birtokában mihamarabb a chondromák mútéti eltávolítása és részleges synovectomia javasolt, amely a lokalizáció és a betegség stádiumától függően történhet artroszkópos vagy nyílt technikával. Késői stádiumban a bokaízületi chondromatosis feltárásból eltávolítható, azonban a már kialakult arthrosis miatt ilyenkor a funkcionális eredmény gyengébb, mint korai stádiumban. Általában igaz, hogy korábbi stádiumban elvégzett mútéttől jobb funkcionális eredmény várható. 


\section{IRODALOM}

1. Abdelwahab I. F., Contractor D., Bianchi S., Hermann G., Hoch B.: Synovial chondromatosis of the lumbar spine with compressive myelopathy: a case report with review of the literature. Skeletal Radiol. 2008. 37(9): 863-867.

2. Ackerman D., Lett P., Galat D. D. Jr., Parvizi J., Stuart M. J.: Results of total hip and total knee arthroplasties in patients with synovial chondromatosis. J. Arthroplasty. 2008. 23. (3): 395-400.

3. Chiang C. H., Jou I. M., Wang P. H., Chern T. C., Huang M. T.: Synovial osteochondromatosis of the second metatarsophalangeal joint: a case report. J. Foot Ankle Surg. 2011. 50. (4): 458-461.

4. Chong C. C., Kneebone A., Kirsh G..: Radiotherapy in the management of recurrent synovial chondromatosis. Australas Radiol. 2007. 51. (1): 95-98.

5. Coolican M. R., Dandy D. J.: Arthroscopic management of synovial chondromatosis of the knee. Findings and results in 18 cases. J. Bone Joint Surg. Br. 1989. 71. (3): 498-500.

6. Csernátony Z., Gáspár L., Mórocz I.: Térdízületi synovialis chondromatosis. Magy. Traumatol. Ortop. 1991. 34. (1): 53-56.

7. Davis R. I., Hamilton A., Biggart J. D.: Primary synovial chondromatosis: A clinicopathologic review and assessment of malignant potential. Human Pathology. 1998. 29: 683-688.

8. Doral M. N., Uzumcugil A., Bozkurt M., Atay O. A., Cil A., Leblebicioglu G.., Tetik O.: Arthroscopic treatment of synovial chondromatosis of the ankle. J. Foot Ankle Surg. 2007. 46. (3): 192-195.

9. Evans S., Boffano M., Chaudhry S., Jeys L., Grimer R.: Synovial chondrosarcoma arising in synovial chondromatosis. Sarcoma. 2014. 2014: 647939.

10. Fukuhara S., Kanazawa Y., Uchida S., Akahoshi S., Yoshioka T., Nakamura T.: Increased levels of chondrocalcin in knee joint fluid in synovial chondromatosis - a case report. Acta Orthop Scand. 2000. 71. (3): 326-327.

11. Fuller E., Bharatha A., Yeung R., Kassel E. E., Aviv R. I., Howard P., Symons S. P.: Case of the month \#166: synovial chondromatosis of the temporal mandibular joint. Can. Assoc. Radiol. J. 2011. 62. (2): 151-153.

12. Galat D. D., Ackerman D. B., Spoon D., Turner N. S., Shives T. C.: Synovial chondromatosis of the foot and ankle. Foot Ankle Int. 2008. 29. (3): 312-317.

13. Kirchhoff C., Buhmann S., Braunstein V., Weiler V., Mutschler W., Biberthaler P.: Synovial chondromatosis of the long biceps tendon sheath in a child: a case report and review of the literature. J. Shoulder Elbow Surg. 2008. 17. (3): e6-e10.

14. Lin Y. C., Goldsmith J. D., Gebhardt M. G., Wu J. S.: Bursal synovial chondromatosis formation following osteochondroma resection. Skelet. Radiol. 2014. 43. (7): 997-1000.

15. McKenzie G.., Raby N., Ritchie D.: A pictorial review of primary synovial osteochondromatosis. Eur. Radiol. 2008. 18. (11): 2662-2669.

16. Milgram J. W. L.: Synovial osteochondromatosis: A histopathological study of thirty cases. J. Bone Joint Surg. Am. 1977. 59-A: 792-801.

17. Muramatsu K., Miyoshi T., Moriya A., Onaka H., Shigetomi M., Nakashima D., Taguchi T.: Extremely rare synovial chondrosarcoma arising from the elbow joint: case report and review of the literature. J. Shoulder Elbow Surg. 2012. 21. (2): e7-11.

18. Muramatsu K., Hashimoto T., Tominaga Y., Taguchi T.: Large synovial osteochondromatosis arising from the interphalangeal joint of the thumb: a case report and review of the literature. Anticancer Res. 2014. 34. (2): 1057-1060.

19. Nagy E., Gömöri É., Krucsó É.: Synovialis chondromatosis a váll izületben. Magyar Radiológia, 1994. 68. (5): $150-151$.

20. Nakanishi S., Sakamoto K., Yoshitake H., Kino K., Amagasa T., Yamaguchi A.: Bone morphogenic proteins are involved in the pathobiology of synovial chondromatosis. Biochem. Biophys. Res. Commun. 2009. 379. (4): 914-919.

21. Németh J., Mersich I., Sárközi A.: Az egyik felső végtag ízületeire lokalizálódó synovialis chondromatosis. Magyar Traumatológia Ortopédia Kézsebészet Plasztikai Sebészet, 1999. 42. (4): 308-314.

22. Ozmeric A., Aydogan N. H., Kocadal O., Kara T., Pepe M., Gozel S.: Arthroscopic treatment of synovial chondromatosis in the ankle joint. Int. J. Surg. Case Rep. 2014. 5. (12): 1010-1013.

23. Perry B. E., McQueen D. A., Lin J. J.: Synovial chondromatosis with malignant degeneration to chondrosarcoma. Report of a case. J. Bone Joint Surg. Am. 1988. 70. (8): 1259-1261.

24. Sah A. P., Geller D. S., Mankin H. J., Rosenberg A. E., Delaney T. F., Wright C. D., Hornicek F. J.: Malignant transformation of synovial chondromatosis of the shoulder to chondrosarcoma. A case report. J. Bone Joint Surg. Am. 2007. 89. (6): 1321-1328.

25. Samson L., Mazurkiewicz S., Treder M., Wisniewski P.: Outcome in the arthroscopic treatment of synovial chondromatosis of the knee. Ortop. Traumatol. Rehabil. 2005. 7. (4): 391-396.

26. Vodajo F., Gannon F., Murphy M.: Visual guide to musculosceletal tumors - a clinical-radiologic-hystologic approach. Synovial chondromatosis. Philadelphia. Saunders. 2010. Chapter 34: 184-188. p.

\section{Dr. Koós Zoltán}

Balassa János Megyei Kórház Ortopédia Osztály

7100 Szekszárd

Béri Balogh Ádám u. 5-7.

kooszo@hotmail.com 